
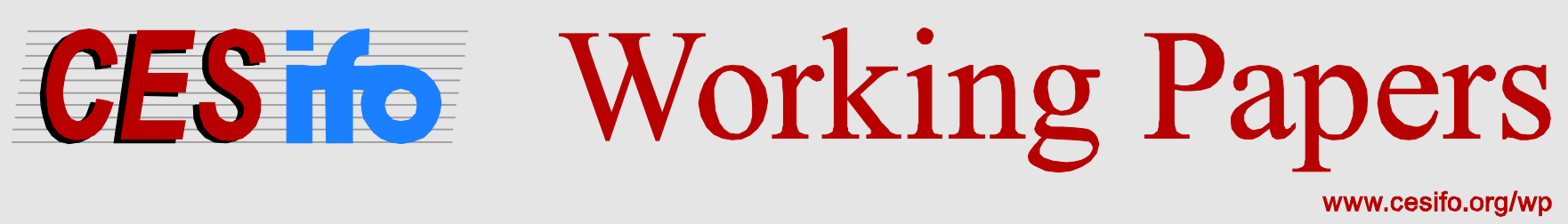

\title{
What if Firms Could Borrow More? Evidence from a Natural Experiment
}

\author{
James R. Brown \\ Gustav Martinsson \\ Christian Thomann
}

\begin{abstract}
CESIFO WORKING PAPER NO. 5458
CATEgory 6: FisCAl POLICY, MaCROECONOMICS AND GROWTH

JULY 2015
\end{abstract}

An electronic version of the paper may be downloaded

- from the SSRN website: Www.SSRN.com

- from the RePEc website: Www.RePEc.org

- from the CESifo website: www.CESifo-group.org/wp 


\title{
What if Firms Could Borrow More? Evidence from a Natural Experiment
}

\author{
Abstract \\ We study the effects of a unique lending program initiated by the Swedish government at the \\ height of the financial crisis that allowed firms to suspend payment of all labor-related taxes and \\ fees. Comprehensive administrative data on all Swedish firms show that firms borrowing from \\ the program have higher rates of debt growth, investment spending, and employment growth \\ compared to otherwise similar firms whose labor taxes were sufficiently low they could not \\ benefit from the program. These results connect the availability of external credit with real \\ activity in entrepreneurial firms in a way that has proved difficult in other settings. \\ JEL-Code: G010, G180, G210, G320, L260, O160. \\ Keywords: credit constraints, financial crisis, debt policy, entrepreneurial finance, employment \\ growth, real activity. \\ James R. Brown \\ Iowa State University, College of Business, \\ Department of Finance \\ 3331 Gerdin Business Building \\ USA - Ames, IA 50011-1350 \\ jrbrown@iastate.edu \\ Gustav Martinsson \\ Royal Institute of Technology (KTH) \& \\ Swedish House of Finance (SHoF) \\ Lindstedtsvägen 30 \\ Sweden - 10044 Stockholm \\ gustav.martinsson@indek.kth.se \\ Christian Thomann \\ Royal Institute of Technology (KTH) \& \\ Centre of Excellence for Science and Innovation Studies (CESIS) \\ Lindstedtsvägen 30 \\ Sweden-10044 Stockholm \\ christian.thomann@indek.kth.se
}

July 22, 2015

We appreciate the helpful comments we received from participants at numerous conferences and seminars, including the Swedish House of Finance, the Swedish Ministry of Finance, Iowa State University, Leibniz University Hannover, the CESifo Venice Summer Institute Workshop on the Economics of Entrepreneurship, the Nordic Tax Economists Meeting in Reykjavik, the SIFR Conference on the Financial Economics of Innovation and Entrepreneurship in Stockholm, the CEPR conference on Entrepreneurial finance, innovation and growth in Helsinki, and the 2014 Paris December Finance Meeting. We are particularly grateful to Laurent Bach, Geraldo Cerqueiro, Rickard Eriksson, Bronwyn Hall, Ulf von Lillienfeld-Toal, Pierre Mohnen, Maria Fabiana Penas, Mark Schankerman, Per Strömberg, and Joacim Tåg for detailed feedback on earlier drafts of the paper. 


\section{Introduction}

Understanding how the supply of credit affects real activity is among the most fundamental but challenging questions in modern finance research. Despite extensive study, clear answers on the real effects of credit constraints remain elusive, especially among the small private enterprises that comprise the vast majority of firms in most economies. One challenge in evaluating the effects of credit constraints in entrepreneurial firms is the general lack of comprehensive data on the financing and investment activities of small private firms (e.g., Robb and Robinson, 2014). The other key challenge is distinguishing the effects of credit supply from credit demand, which is particularly difficult to overcome because demand controls are imperfect and supply and demand shocks tend to be positively correlated. ${ }^{1}$

In light of these challenges, this paper combines administrative data on the full economy of entrepreneurial firms in Sweden with a unique natural experiment that temporarily increased the supply of credit to Swedish firms. Our analysis focuses on a lending program launched at the height of the worldwide financial crisis that effectively allowed any firm paying labor taxes to borrow funds from the Swedish government at a fixed interest rate. Specifically, by checking a box on a monthly tax form, firms could temporarily postpone (initially for up to one year) payment of up to two months' worth of labor-related taxes and fees. These payments are relatively high in Sweden and include fees to cover employees' social security, government provided health insurance, workers compensation, and even employees’ personal income tax. ${ }^{2}$ Any unpaid taxes were treated as a loan from the Swedish government, and all such loans were charged a relatively high interest rate (roughly twice the market rate on similarly sized loans) to discourage firms that were not liquidity constrained from taking the funds. Unlike the typical loan, firms did not have to post collateral, submit paperwork, or go through a formal approval process to participate in the lending program.

Two other features of the lending program make this an ideal setting to evaluate the economic consequences of external credit constraints. First, since the program was launched at the height of the

\footnotetext{
${ }^{1}$ The literature on testing for financing constraints has long struggled with this issue. For example, see the discussions in Fazzari, Hubbard, and Petersen (1988), Almeida, Campello, and Weisbach (2004), Almeida and Campello (2007), and Lemmon and Roberts (2010).

${ }^{2}$ The program thus offered the typical firm a substantial capital injection: in our sample, average program proceeds-to-assets correspond roughly to the size of the average firm's capital expenditures-to-assets ratio.
} 
crisis, we observe a positive shock to the supply of credit at precisely the time that demand-side effects are, if anything, depressed (e.g., Kahle and Stulz, 2013). Thus, in sharp contrast to the challenges faced in most studies on finance and the real economy, in our setting the simultaneity of supply and demand for credit works against us finding strong evidence that access to credit matters for real activity. Second, though the option to delay tax payments was available to essentially all Swedish limited liability corporations, ${ }^{3}$ the amount of funding that was available through the program differed sharply across firms based on the size of their monthly labor tax bill. We exploit the crossfirm heterogeneity in the potential funding that was available from the lending facility in our empirical tests.

Our analysis starts with micro-level data for the entire universe of limited liability firms in Sweden. To evaluate the effects of the lending program, we use a difference-in-differences approach that compares outcomes in firms that took advantage of the lending program (loan firms) with those that did not (no loan firms). In addition to comparisons with the full economy of no loan firms, we use the cross-firm heterogeneity in the amount of potential funding the lending program provided to build a matched sample of control firms. Namely, since the amount of funding available to each firm is a direct function of the amount of labor related taxes paid (which itself is a function of the firm's total wage bill) the one exogenous determinant of whether firms select in or out of the lending program is the size of their wage bill at the time the policy was introduced. We thus use information on firm-level wage bills to construct a proxy for each firm's loan capacity, which is the maximum amount of funding the firm could potentially receive from the lending program. We then perform matching on observable financing and investment variables between firms utilizing the lending program and the set of firms in the bottom quartile of loan capacity. This approach gives us a control group of firms that matches the loan firms in key dimensions in the pre-crisis period - e.g., cash flow, leverage, and investment - but simply was not in a position to obtain significant funding from the lending program given the way it was structured.

\footnotetext{
${ }^{3}$ The only firms restricted from taking the loan were firms with an outstanding payment default at the debt collector's office. A very small fraction of firms fall into this category (around 0.03 percent of Swedish firms).
} 
We start by testing whether the firms using the lending program increase overall levels of debt. If a firm simply uses the loan proceeds to offset other debt, then the lending facility allowed firms to substitute toward alternative (and perhaps cheaper) types of debt, but use of the facility does not indicate the presence of financing constraints and access to the loan funds should not have important effects on real activity. On the other hand, evidence that debt levels increase for firms using the lending facility suggests that they face binding financing constraints, which are at least partially relaxed by the expanded access to external credit the program provides (Banerjee and Duflo, 2014).

Using both the full- and matched-samples, we find a significant positive differential increase in debt in the firms that use the lending facility relative to other firms. Notably, there is essentially no difference in debt levels or trends across loan and matched firms prior to the implementation of the lending facility. However, after the facility is introduced, debt levels are substantially higher in loan firms compared to the control firms. Moreover, focusing only on the sample of loan firms, we find a roughly dollar-for-dollar relation between the amount of funding the firm received from the lending facility and the change in its overall level of debt, as expected if access to the lending program relieved binding credit constraints during the crisis period.

Next, we use the same general approach to test whether access to the lending facility impacts capital investment and employment growth. Consistent with the findings on debt growth, firms using the lending facility have differentially higher rates of capital investment and employment growth relative to various control samples. Further, if we focus only on the sub-set of firms that use the lending facility, we find a strong positive relation between the amount of funding the firm obtained from the facility and its subsequent rates of fixed capital investment and employment growth. These tests underscore that the proceeds are used for real economic activity in firms facing credit constraints and not as short-term life-support for highly distressed firms. Overall, our findings point to an important link between access to external credit and real activity in an important sub-set of entrepreneurial firms.

Our work adds to the literature on financing conditions and firm behavior during the financial crisis. Much of this research focuses on evaluating the impact of financing constraints during the crisis and identifying the internal adjustments firms make in response to these constraints. For 
example, prior studies focus on liquidity management, divestitures of fixed assets, cuts to investment spending, adjustments to payout policy, and borrowing behavior in response to the credit crisis (e.g., Campello, Graham, and Harvey, 2010; Duchin, Ozbas, and Sensoy, 2010; Campello, Giambona, Graham, and Harvey, 2011; Bliss, Cheng, and Denis, 2013; Iyer, Lopes, Peydro, and Schoar, 2014; Brown and Petersen, 2014). While much of this evidence supports the idea that a lack of credit in the crisis had important real effects, distinguishing the effects of lower credit supply from reduced investment demand is (as always) a significant challenge. Indeed, Kahle and Stulz (2013) argue that investment and financing patterns in US firms in the crisis are better explained by lower investment demand than by a reduction in credit supply. By focusing on the differential effects of expanded access to credit among a sub-set of firms, our work offers quasi-experimental evidence on the real consequences of credit supply in a crisis. Furthermore, given that firms did not have to provide any collateral to obtain this credit, our results are - in a unique way - unaffected by changes in the value of a firm's collateral over the business cycle (e.g., Bernanke and Gertler, 1989). In sum, our findings directly connect improved access to external credit with investment and employment in a way that is difficult in other settings.

More broadly, our work contributes to an extensive literature that tests for the presence of financing constraints and evaluates the impact these constraints have on firm behavior. Starting with influential work by Fazzari, Hubbard, and Petersen (1988), a large portion of this literature focuses on estimating the impact that shocks to internal cash flow have on various firm activities. ${ }^{4}$ Our work differs in several notable ways. First, we follow a relatively small number of studies and use a quasinatural experiment to evaluate the impact of financing constraints (e.g., Rauh, 2006; Lemmon and Roberts, 2010). A notable feature of the experiment we study is that the shock to finance is not only exogenous to a given firm, but is also, if anything, inversely related to economy-wide investment opportunities. Second, in addition to real firm activities, our tests evaluate how access to credit

\footnotetext{
${ }^{4}$ For example, studies have explored the connections between internal cash flow and: i) fixed capital investment (Fazzari, Hubbard, and Petersen, 1988; Gilchrist and Himmelberg, 1995; Erickson and Whited, 2000; Almeida and Campello, 2007; Chen and Chen, 2012), ii) investment in cash reserves, working capital, and inventories (Almeida, Campello, and Weisbach, 2004; Fazzari and Petersen, 1993; Carpenter, Fazzari, and Petersen, 1998), iii) R\&D investment (Himmelberg and Petersen, 1994; Brown, Fazzari, and Petersen, 2009), and iv) advertising expenses (Fee, Hadlock, and Pierce, 2009). A related literature studies how financing constraints influence entrepreneurial activity (e.g., Kerr and Nanda, 2009).
} 
impacts debt ratios. These results not only indicate a connection between financing constraints and leverage adjustments (e.g, Öztekin and Flannery, 2012), but, as Banerjee and Duflo (2014) show, evidence that firms use new credit to expand debt levels rather than substitute for other borrowing indicates the presence of binding credit constraints and suggests that firms want to borrow more. Third, we focus on the effects of a shock to the supply of external finance rather than the availability of internal finance, and we do so in an extensive sample of small private firms. The evidence in Robb and Robinson (2014) shows that small entrepreneurial firms rely extensively on external bank credit, which could either suggest that credit constraints are not a major obstacle for small firms (since they are evidently able to raise debt to finance investment opportunities), or that shocks to credit supply will be particularly impactful on the activities of these firms (since they depend on costly debt at the margin). Our work suggests that credit supply does matter, at least among the sub-set of entrepreneurial firms with sufficient growth and investment opportunities.

In this way, our study is relevant for recent discussions about which firms in the economy are financially constrained (e.g., Hadlock and Pierce, 2010). For example, Farre-Mensa and Ljungqvist (2013) argue that standard proxies for financing constraints do not measure constraints, at least among publicly traded firms. Taking our findings on firm use of the lending facility as evidence of binding credit constraints, we can identify the factors most associated with financing constraints in a broad sample of small, private firms. Using this perspective, a firm is more likely to use the lending facility if it enters the crisis with relatively higher sales growth, leverage, and capital expenditures, and relatively lower cash flow and age. These results suggest that the intersection of growth opportunities and financial resources is key to understanding where financing constraints are most binding, and they show that some proxies for constraints widely used in the literature - namely firm size - may not be particularly informative about financing constraints when looking beyond the sub-set of publicly listed companies used in most studies. ${ }^{5}$ One reason for the weak relation between firm size and

\footnotetext{
${ }^{5}$ For instance, the average financially constrained firm in Hadlock and Pierce's (2010) sample has a book value of total assets of around 350 million US dollars, which is small relative to other publicly listed US firms, but not at all small in an absolute sense. In sharp contrast, the average book value of total assets among the firms in our sample that used the lending facility is roughly two million US dollars (or SEK 14.8 million). Of course, in our particular case, to the extent that payroll taxes are relatively less important (as a share of assets) for smaller
} 
financing constraints in an economy-wide sample of firms is that almost all firms in such samples are extremely "small” by conventional measures. Moreover, if the majority of small business owners that comprise such a broad sample have little interest in expanding (e.g., Hurst and Pugsley, 2011), firm size alone will be a poor predictor of financing difficulties. Indeed, though some caution is warranted given the timing and structure of the lending program, we find that a relatively small fraction of all Swedish firms take advantage of the opportunity to borrow more, suggesting that the majority of small firms lack significant growth opportunities or do not have strong growth ambitions. ${ }^{6}$

Finally, our evidence adds to the literature evaluating the effects of various public programs targeted at mitigating financing constraints in entrepreneurial firms (e.g., Bach, 2014; Banerjee and Duflo, 2014; Lelarge, Sraer, and Thesmar, 2010; and Lerner, 1999). Numerous programs around the world attempt to mitigate firm financing constraints over the long-run, but these programs typically take the form of government grants, subsidies, and targeted loans, and thus are not designed to alleviate short-term effects of constraints in a crisis. Our findings show that financial policies designed solely for transitory and potentially severe financial market disruptions can have economically important effects.

\section{Institutional design and data}

\subsection{The law of the postponement of labor taxes}

In the the final quarter of 2008, the Swedish parliament passed the law of the postponement of labor taxes (SFS 2009:99). The law was passed on February 26, 2009, went into effect on March 9, 2009, and was administered by the Swedish tax agency (Skatteverket). The purpose of the law was to offer firms a temporary liquidity boost by allowing them to postpone paying two months' worth of labor related taxes for up to one year. In Sweden, labor related taxes comprise employees’ income taxes, social security payments, and payroll taxes. Given that labor related taxes are relatively high in

firms, then the structure of the lending facility can partially explain why larger firms were more likely to take advantage of the program.

${ }^{6}$ In the same way that the simultaneity of credit supply and demand clouds inference about the existence of financing constraints in most studies, it clouds inference about the lack of constraints in our study. In particular, firm-level demand for credit may have been temporarily depressed during the crisis, providing an alternative explanation for firms passing on the opportunity to borrow more. For this reason, we base most of our conclusions on the behavior of the firms that did borrow funds in relation to the control firms that were excluded from the program for structural reasons. 
Sweden, postponing two months' worth of these payments represents a potentially substantial liquidity boost, a point we return to (and quantify) below. All loans were charged an interest rate corresponding to 5.3\% per annum and were due to be paid in full by January 2011. Thus, the policy was designed to assist firms facing temporarily severe financing constraints, not subsidize firms with ample internal cash flows or bail out firms in financial distress. ${ }^{7}$ In accounting terms, firms that postpone their tax payments incur a liability that shows up on the firm's balance sheet.

The loan program has several interesting properties. First, by targeting a firm's labor taxes rather than profit taxes, the lending facility does not require that the firm is profitable in order to access the funds. However, since the funding available through the program is a function of labor related taxes, there is substantial heterogeneity across firms in the extent to which they can benefit from the policy. Second, since the lending facility was accessible through the monthly labor tax form it was straightforward for the firm to access the funds and for the tax agency to administer the loan. The estimated cost of administration is Swedish Krona (SEK) 4.5 million ( 600,000 dollars), or just SEK 258 per loan ( 35 dollars). Third, the interest rate was set so as to not crowd out other kinds of loans. The interest rate in March 2009 reported in the monetary financial statistics (MFI) for corporate loans below one million EUROs was equal to 2.64 percent. ${ }^{8}$ Given the substantially higher rate on lending facility funds, it is unlikely that firms in general would find it attractive to use funds from the lending program funds to pay down market loans. Indeed, our findings below show that firms did not simply use the funds to reduce other outstanding liabilities.

\subsection{Data and sample}

We use a comprehensive administrative database covering all limited liability companies in Sweden. ${ }^{9}$ Incorporation is by far the most important legal structure for companies in Sweden. For example, limited liability corporations account for almost $90 \%$ of total business turnover in Sweden,

\footnotetext{
${ }^{7}$ This is also stressed in the administration's proposal that accompanies the law (prop. 2008/09:113): The law aims to assist firms that are fundamentally healthy but due to temporary lack of lending face liquidity constraints (a translation from the law proposal which is in Swedish).

${ }^{8}$ Description: http://www.ecb.europa.eu/stats/money/interest/interest/html/index.en.html.

${ }^{9}$ The database is called FRIDA and it is maintained by Statistics Sweden. For privacy reasons we cannot see firms’ real names or actual unique identifier, but we can track the same firm over time.
} 
while sole proprietorships and unlimited partnerships each make up just $1.7 \%$ of total turnover. ${ }^{10}$ Thus, we start with data on essentially the entire universe of firms in Sweden. The database is constructed from firms' corporate income tax filings and contains balance sheet and income statement information. It also includes information on a number of other firm characteristics, including whether the firm is publicly listed, the number of workers it employs, and its primary industry classification. The initial data is at the (unconsolidated) company level. In order to achieve better comparability with other studies that use consolidated accounting data for entire firms (e.g., Compustat), we consolidate the company data using information available in the database on corporate ownership structure. Using the consolidated data, we refer to each consolidated corporation as a "firm". In order to focus on active economic enterprises, we restrict the sample to firms with at least five employees and total sales of at least one million EUROs. ${ }^{11}$ Even with this sample restriction, we are left with a sample comprised largely of very small, private firms. ${ }^{12}$ After imposing these restrictions and dropping firms in financial and regulated industries, our final sample consists of around 25,000 unique firms.

Our second source of data provides information on the firms that used the lending program. This data is maintained by the Swedish tax agency. The firm-level database provides a unique identification number for each firm, enabling us to match the information on firm use of the lending facility to the firm-level dataset described above. In the final sample, the total number of unique firms taking a loan from the program is 1,267 . We focus primarily on the period 2007-2010, giving us two years of data prior to the initiation of the lending facility.

\footnotetext{
${ }^{10}$ Tax Statistical Yearbook of Sweden 2013, Table 10.3, p. 220.

${ }^{11}$ We have also studied broader samples that imposed no minimum sales threshold and included any firm with a non-zero employee count. This resulted in a sample heavily weighted toward very tiny firms - for example, over half of all firms in the broader sample had two or fewer employees. Since the Swedish tax system makes it attractive for individuals to create shell companies for tax planning and income shifting reasons, we believe many of these low/no employee firms are not active enterprises. While the results in the paper are robust to using this broader sample of firms, we believe it is more appropriate and relevant to base the analysis on firms that are clearly economically active.

${ }^{12}$ For example, Eurostat considers any firm with less than ten employees or two million EUROs in sales a "micro" enterprise. If we follow Eurostat's definition and focus on only "small” and larger firms, our sample size falls by half but our findings do not change.
} 


\subsection{Loan characteristics}

Table 1 reports information on firm use of the lending facility in 2009 and 2010. In 2009, a total of 1,109 firms used the lending facility. In aggregate, these firms had a total borrowing capacity (our estimate of the maximum amount they could have gotten from the program) of 5.7 billon SEK, and actually borrowed approximately 4.28 billion SEK. Using the local currency conversion unit provided by the World Bank, the total amount of funding administrated through the program in 2009 corresponds to around 578 million US dollars. In 2010, another 445 firms took a loan from the facility. Of the firms using the lending facility in 2010, 158 did not take any funds in 2009, while 287 had already used the lending facility to some extent in 2009. Across both years, the total amount of funds accessed from the lending facility is 4.64 billion SEK (627 million US dollars).

The final two columns in Table 1 contain information on loan proceeds relative to the size of the firm. The average (median) loan proceeds-to-assets ratio is $0.044(0.031)$ in 2009 and 0.034 (0.020) in 2010. As we discuss in more detail below, the proceeds provided by the lending facility are non-trivial relative to other financing sources and to firm-level real activities. For example, the loan amounts are roughly comparable to the annual capital expenditure-to-assets ratios in our sampled firms.

\subsection{Sector composition}

Table 2 reports the distribution of sample firms across sectors. We report firm counts for eight specific industry groupings, plus one grouping containing all "Other industries". This approach follows the industry groupings in Cerqueiro, Ongena, and Roszbach (2014). Columns (1) and (2) contain the count of loan firms, and fraction of all loan firms, accounted for by each sector. Columns (3) and (4) report the same information for the full sample of firms (loan and no-loan firms). The majority of loan firms come from four industries: Manufacturing, Other services, Retail and trade, and Construction. In broad terms, the distribution of loan firms is similar to the economy-wide distribution of firms. The most notable exceptions are that Manufacturing firms are over-represented among loan firms (relative to the full economy), while firms in Retail and trade account for considerably larger fraction of economy-wide firms (32\%) than loan firms (18.7\%). 
In column (5) we report the average interest cost per unit of debt for firms in each sector. A potential explanation for firm use of the lending facility is that the loan firms are simply risky, distressed firms on the brink of insolvency. In this case, use of the lending facility may primarily reflect the efforts of distressed firms to delay bankruptcy, rather than the efforts of financially constrained (but otherwise healthy) firms to exploit their investment and growth options. Distinguishing between these alternative stories is important if we are to draw inferences from this setting about the real consequences of financing constraints more generally. While the evidence we present later in the paper linking use of the lending program with firm investment and employment growth will more directly address this issue, as an initial check, the values in column (5) provide some broad evidence on whether firms from industries with relatively high average interest costs are more likely to use the lending facility. The idea behind this evidence is that firms in financial distress likely carried substantial interest obligations that would have been lessened by access to the lending program. But the values in column (5) show that the firms using the lending program are not disproportionally drawn from sectors with high ex ante interest expenses. ${ }^{13}$ In fact, the correlation coefficient between the fraction of loan firms accounted for by a given sector and the average interest cost in that sector is close to zero and actually slightly negative (-0.107).

\section{Who took the loan?}

\subsection{Loan firms versus no loan firms: Summary statistics}

Table 3 illustrates the key differences between the firms that used the lending facility (Loan firms) and all other firms in the economy (Other firms). We pool observations over the full sample period (2007-2010) and report separate sample means, medians, and standard deviations of key firm characteristics for the Loan firms and Other firms. All of the comparisons are very similar if we focus only on 2007 and 2008, the years prior to the introduction of the lending facility. All variables are winsorized at the $1 \%$ level before computing the statistics reported in Table 3.

We start with information on the firm characteristics we focus on later in the study: annual change in debt to total assets (Debt growth), capital expenditures to total assets (CAPX), and the

\footnotetext{
${ }^{13}$ We thank Bronwyn Hall for suggesting this check.
} 
annual change in employment (Employment growth). In general, the loan firms tend to have higher debt growth, capital investment, and employment growth compared to the other (no loan) firms. Perhaps most importantly, for the typical (median) firm not accessing the lending facility, employment growth is zero and capital expenditures are relatively small (2.6\% of assets). Moreover, debt growth in the no loan firms is slightly negative. In general, firms choosing to sort away from the lending facility appear to have less need for external capital.

This inference is strengthened by the values in the remainder of Table 3, which consist of a set of variables commonly used in the financing constraints literature as predictors of financing constraints (e.g., Hadlock and Pierce, 2010). Compared to the firms not using the lending facility, the Loan firms have lower cash flows relative to assets (Cash flow), lower cash holdings to total assets (Cash), lower dividends to total assets (Dividend), lower sales to total assets (Sales), but higher leverage (Debt) and higher sales growth (Sales growth). These outcomes are consistent with the idea that Loan firms are much more likely to face binding financing constraints than the firms that did not participate in the lending program. In particular, while for the median firm in the no loan sample (Other firms) the cash flow ratio is more than four times greater than the capital expenditure ratio (0.105 versus 0.026$)$, among loan firms the median cash flow ratio is only slightly larger $(0.050$ compared to 0.034). Moreover, the Loan firms carry substantially smaller reserves of cash and likely possess less unused debt capacity given their relatively high debt ratios. Together, these statistics suggest that access to funding, particularly during a crisis period, is likely much more important for the activities of the Loan firms compared to other firms in the economy.

We proxy for firm size using the size of the Wage bill (in logs), in part because funding from the loan amount directly depends on the amount of labor taxes the firm pays. At both the mean and median, firms using the lending facility have larger wage bills than other firms. To the extent that use of the lending facility indicates the existence of financing constraints, as argued above, it might seem surprising that the loan firms tend to be larger. There are two reasons why size works differently in our study compared to previous work on financing constraints. First, we have a sample that comes closer to containing the entire population of firms in a country, the vast majority of which are very small private firms that are not growing, and may in fact have no interest in growing (e.g., Hurst and 
Pugsley, 2011). As an example from the literature, the average firm in the more constrained sample in Hadlock and Pierce (2010, p. 1917) has total assets of 350 million US dollars. A firm of that size would (easily) be in the top quintile in firm size in our sample. Thus, though Loan firms are larger than Other firms, in an absolute sense they are still quite small. Second, even if they needed funding, the structure of the lending program was such that firms with very low wage bills had no reason to participate.

The final two variables in Table 3 are directly related to the loan program. First, we compute a proxy for the maximum amount of funding each firm could have obtained from the lending facility. This amount corresponds to roughly $9 \%$ of the firm's annual wage payment. We thus take $9 \%$ of the annual wage bill, normalize by total assets, and call the variable Loan capacity. Most importantly, and not surprisingly, Loan capacity is relatively larger for the loan firms. Specifically, average Loan capacity for the firms using the lending facility is roughly $7.5 \%$ of total assets, whereas for the no loan firms it is around $6.4 \%$. Notably, for the firms using the lending facility, loan capacity is slightly larger than annual cash flows and only marginally smaller than their stock of cash reserves. Thus, at least for some firms, the potential funding offered by the lending facility was non-trivial. Indeed, as discussed above, the average Loan amount is 0.041 (and the median is 0.027), which is roughly comparable to the loan firms' average capital expenditures over the full sample period.

\subsection{Firm characteristics and the probability of taking a loan}

In Table 4 we report results from a logit regression where an indicator for whether or not the firm took the loan is the dependent variable. We use firm characteristics from 2008, the year immediately preceding the introduction of the lending facility, and we include a full set of industry fixed effects. In column (1) we include all of the firm characteristics reported in Table 3 except the Loan capacity measure (which is highly co-linear with Wage bill). We add Loan capacity in column (2). In either case, the conditional probability that a firm takes the loan in 2009-2010 (based on 2008 firm characteristics) increases with sales, sales growth, the size of the wage bill, leverage, capital investment, employment growth, and loan capacity. 
On the other hand, the probability a firm uses the lending facility decreases with cash flow, firm age, cash holdings, and dividends. These outcomes are generally consistent with the descriptive statistics discussed above, and provide further support for the idea that firm use of the lending facility was driven in an important way by financing considerations. As before, the only characteristic that does not behave as in the financing constraints literature is firm size (Wage bill). To the extent that making use of the lending facility directly indicates that firms are financially constrained, the findings in Table 4 shed light on the types of firms most constrained in a crisis. Namely, it is younger firms with higher investment opportunities and growth options but limited internal resources and less unused debt capacity.

\subsection{Loan capacity and the lending facility}

The results in Table 4 show that Loan capacity is an important determinant of whether or not firms used the lending facility. To further illustrate the sharp heterogeneity in use of the lending facility across firms with different loan capacity, Table 5 reports information on firm use of the lending facility across different quartiles of firm Loan capacity. We focus on use of the lending facility in 2009, the year it first became operational and the year that most lending takes place. In Panel A we report firm counts (and overall sample shares) by Loan capacity quartile and in Panel B we focus on the actual proceeds raised from the lending program.

The first column in Table 5 shows that a total of 1,109 firms use the lending facility in 2009 (or $4.4 \%$ of the firms in our sample). Firms in the smallest quartile (column (2)) of Loan capacity are less likely to use the lending program and, more importantly, even when they do use the program they raise very little capital. For example, the average (median) Loan proceeds in the lowest quartile is just $1.1 \%(0.9 \%)$ of assets. The values in columns (3)-(5) indicate an increasing use of the lending program among firms in the higher Loan capacity quartiles, with the firms having higher Loan capacity borrowing substantially more from the lending facility. For example, the average (median) Loan amount increases from 2.3\% (2.2\%) of assets in the second quartile of Loan capacity to $8.8 \%$ (7.3\%) in the fourth quartile. These results show that the design of the lending facility makes it more attractive among firms with high labor taxes relative to total assets. 


\section{Testing the effects of the lending program}

\subsection{Tests}

We are primarily interested in understanding whether access to the lending facility affected financial policy and real firm activity during the crisis. We start by exploring how firms' debt levels change as a consequence of accessing the lending facility. This test follows the ideas in Banerjee and Duflo (2014), who test for financing constraints in India by studying how a directed lending program affects firms' debt levels. They argue that financially constrained firms will use the directed credit to increase debt levels, whereas unconstrained firms will not increase overall debt because they simply replace existing debt with the directed (and cheaper) credit. In addition to testing the lending facility's impact on leverage, we evaluate its effects on two real outcomes: capital investment $(C A P X)$ and employment (Employment growth). Financing constraint studies have long focused on fixed capital investment (e.g., Fazzari, Hubbard, and Petersen, 1988), and there is increasing interest in understanding the impact financing constraints have on labor market outcomes, particularly among policymakers (e.g., Chodrow-Reich, 2014; Pagano and Pica, 2012).

We conduct two additional tests to more carefully evaluate the financing constraints hypothesis. First, we check the within firm relation between the size of the loan proceeds and the change in debt: not only should firms using the lending facility exhibit an increase in leverage if they are constrained, but the elasticity of changes in debt to loan proceeds should be around one. Second, we estimate the within-firm relation between loan proceeds and real investment and employment growth. Estimating how firms use the loan proceeds is important for quantifying the real effects of the lending program, and evidence linking program funding with long-term investments in fixed capital and employment growth helps address concerns that distressed firms just trying to cover their short-run liquidity needs are the primary beneficiaries of the program.

\subsection{Control group construction}

Table 3 showed just how different loan firms are to all other firms in the economy. In particular, recall that the loan firms invest more (CAPX), have higher leverage (Debt) and sales growth (Sales growth), and they are larger (Wage bill), whereas the no loan firms have higher cash 
flows (Cash flow), cash holdings (Cash), and dividends (Dividends). All of the above mentioned characteristics are endogenous factors that determine whether firms choose to use the lending facility. The one exogenous factor that makes the lending facility relatively more attractive for some firms than for others is ex ante loan capacity relative to assets (Loan capacity).

We exploit the fact that the lending facility offered little or no substantive funding for firms with relatively low payroll tax payments. This institutional design of the lending facility makes it possible to proxy for the counterfactual: What would the borrowing behavior and real activity in loan firms look like if they did not have access to the lending facility? Specifically, we construct a control group of firms from the set of firms with low Loan capacity, and then compare outcomes from this control group to the treated (loan) firms. Our objective is to compare firms that are similar on observable dimensions, but differ markedly in how much potential funding the lending facility provided (i.e., how much the supply of credit changed for each firm as a result of the loan program).

To construct the control group of firms we start by focusing only on the firms in the bottom quartile in Loan capacity in the pre-crisis period of 2007-2008 (roughly 6,500 firms). We then perform coarsened exact matching (Blackwell, Iacus, King, and Porro, 2009) between this group of control firms and the firms in the top quartile in Loan capacity that used the lending facility. Since the loan firms differ slightly in terms of industry composition relative to the full sample as shown in Table 2, and because asset structure and capital structure systematically differs across industries, we find firms within the same industry that are as similar as possible in terms of the three outcome variables (Debt, CAPX and Employment) and the three financing variables (Cash flow, Cash, and Dividends). The first-order objective is to find a control group of firms that is similar to the loan firms in the matching variables, while sample size is of second-order importance. We start with the 332 treated (loan) firms in the top quartile of loan capacity and 6,500 (potential) control firms. After coarsened exact matching within industry and in the six dimensions mentioned above, we end up with 180 treated firms and 577 control group firms. While the reduction in sample size is large, the matching leaves us with two groups of firms that are considerably more similar than the overall summary statistics reported in Table 3 . We also report results using alternative matching procedures that give us a larger sample size. 
Table 6 reports descriptive statistics on the Loan firms and Control firms. Most importantly, Debt levels are essentially identical in the treated and control groups, and the two groups of firms are also similar in terms of Dividends and Cash. Even after the careful matching we cannot reject differences in CAPX, Employment, and Cash flow, though the magnitudes of these differences are relatively small, particularly compared to in Table 3. In the formal tests that follow we directly control for these firm characteristics to address any lingering concerns that our loan- and matched-firms remain systematically different. Of course, by construction, the two sets of firms differ substantially in terms of Loan capacity. The treated firms have a Loan capacity of 0.074 compared to a capacity of just 0.017 for the control group.

\subsection{Regression specification}

To more formally quantify the effects of the lending facility on firm financing and subsequent real outcomes, we estimate the following difference-in-difference specification:

$$
\text { Outcome }_{i, t}=\beta_{0}+\beta_{1} L P_{t}+\beta_{2} L F_{i}+\beta_{3}\left(L P_{t} \times L F_{i}\right)+\beta_{4} X_{i, t}+\varepsilon_{i, t} .
$$

In equation (1), Outcome $e_{i, t}$ is either the annual change in Debt (Debt growth), annual rate of capital expenditures to total assets (CAPX), or annual change in log employment (Employment growth). The $\beta_{0}$ coefficient is the intercept term. The term $L P_{t}$ is an indicator variable taking on the value one during the loan period (2009-2010), and zero in the years before (2007-2008). $L F_{i}$ is an indicator variable taking on the value one if the firm accessed the lending facility, and zero otherwise. The interaction term, $L P_{t} \times L F_{i}$, captures the interaction between loan firms and loan period years. Consequently, $\beta_{3}$ captures the differential effect of the lending facility on loan firms in the crisis period and represents the treatment effect. $\boldsymbol{X}$ is a vector of control variables. We report results using alternative sets of control variables and fixed effects, including the lagged value of the outcome variable (Outcome $\left.e_{i, t-1}\right)$, Cash flow, Firm age, Cash, Dividends, Wage bill, Sales, and Sales growth. 


\section{Evidence on the effects of the lending facility}

\subsection{Full sample results}

We start by using the full sample of firms and estimating equation (1) with Debt growth as the dependent variable. We report these full sample results in Table 7. We begin in the first column by estimating specification (1) without any control variables or fixed effects. The coefficient estimate on the interaction term $(L P \times L F)$ is positive and significant, indicating that debt growth is 2.3 percentage points faster for Loan firms than for other firms in the economy during the crisis period. Further, the large, positive point estimate on the $L F$ coefficient indicates that debt growth in the loan firms 1.4 percentage points faster throughout the entire sample period compared to other firms in the economy. Finally, the coefficient on the Loan period dummy variable is -0.015 , indicating that debt growth falls, on average, by 1.5 percentage points during the loan period across all firms, as expected since this coincides with the aftermath of the financial crisis. We add industry fixed effects in column (2) and the results are virtually unchanged.

In column (3) of Table 7 we add a set of firm-level control variables and reach similar conclusions. Specifically, controlling for initial debt levels and other firm-specific characteristics leaves the interaction effect unchanged and inflates the $L F$ coefficient (from 1.4 to 2.7 percentage points), further highlighting the fact that Loan firms have significantly faster debt growth throughout the 2007-2010 sample period when compared to the full sample of no-loan firms. In column (4) we add year fixed effects, which causes the Loan period indicator to fall out of the regression but leaves the results unchanged otherwise. Finally, in columns (5) and (6) we re-estimate specification (1) with a firm fixed effects estimator and find similar results. In column (5) we include firm fixed effects only, while in column (6) we include both firm- and year-fixed effects. ${ }^{14}$ In either case, the interaction effect is positive and statistically significant, though slightly smaller in magnitude than in the initial specifications. The fixed effects regressions suggest a differential annual rate of debt growth for Loan firms of around 1.8 percentage points. Overall, the results in Table 7 support the unconditional

\footnotetext{
${ }^{14}$ We omit the lagged level of Debt from these specifications to avoid the well-known dynamic panel bias (Nickell, 1981).
} 
descriptive statistics reported earlier: relative to the full sample, firms using the lending facility experience differentially faster debt growth during the years they access the lending facility.

We proceed by estimating specification (1) using CAPX and Employment growth as dependent variables and report the results in Table 8 . In the first three columns of Table 8 we estimate specification (1) with CAPX as the dependent variable. Using a pooled OLS estimator with industry fixed effects and a full set of firm control variables (column (1)), we find a positive and significant coefficient on the key interaction term $(L P \times L F)$, indicating that loan firms invested relatively more during the loan period than other firms in the economy. But both the loan firm $(L F)$ and the loan period $(L P)$ indicators are also positive and significant, suggesting that loan firms always invest more than other firms (consistent with the overall descriptive statistics in Table 3). In columns (2) and (3) we add year fixed effects and firm fixed effects, respectively, and find very similar results.

In the last three columns of Table 8 we estimate the difference-in-difference specification with Employment growth as the dependent variable. In each case we find a positive and statistically significant coefficient on the interaction term $(L P \times L F)$, indicating relatively faster employment growth for loan firms in the crisis period relative to other firms in the economy. These results are inconsistent with the idea that poorly performing distressed firms are the primary users of the lending program.

\subsection{Matched sample results}

A potential concern with the results in Tables 7 and 8 is that the control variables fail to adequately address the fact that firms using the lending facility are fundamentally different from the other (no loan) firms in the economy. We thus proceed by estimating the same difference-indifference regression, but in this case using alternative samples of matched firms. In Table 9 we estimate specification (1) with the annual change in Debt as the dependent variable. In the first four columns we use the main matched sample, constructed by matching the bottom quartile of no-loan firms in terms of Loan capacity to the loan firms in the top quartile of Loan capacity. In the final two columns we consider an alternative matched sample, wherein all loan firms in the top three quartiles of Loan capacity are matched with no-loan firms in the bottom quartile of Loan capacity. 
We present estimation results without any firm controls or fixed effects in column (1). The loan firm dummy variable $(L F)$ is small and insignificant, showing that, relative to the matched sample, loan firms do not always have higher debt levels. The loan period indicator is negative and significant, showing that debt levels fall for all firms in the crisis years. Most importantly, the interaction term $(L P \times L F)$ is positive, significant, and actually larger in magnitude than in the full sample regressions reported in Table 7. The positive interaction term indicates differentially higher debt growth for the firms using the lending program of around 4.8 percentage points per year. In other words, assuming the matched (low Loan capacity) firms capture the relevant counterfactual, the estimates suggest that access to the lending facility allowed firms to significantly increase their levels of debt.

In column (2) of Table 9 we include firm and year fixed effects (which absorb the $L F$ and $L P$ indicators) and find almost identical results as in column (1). In column (3) we drop the firm and year fixed effects and instead include industry fixed effects and the firm control variables. Once again, the estimate on the $(L P \times L F)$ interaction term is positive, significant, and sizeable in magnitude. Finally, in column (4) we include firm and year fixed effects together with the vector of time-varying firmspecific control variables, and continue to find a sharp differential increase in debt growth among the sub-set of firms with access to the lending facility.

In the last two columns in Table 9 we estimate the same specifications using a slightly different matched sample. In this case, rather than using only firms in the top quartile of Loan capacity, we match loan firms in the top three quartiles of Loan capacity to firms with the lowest potential to benefit from the lending facility. We do this because it results in a slightly larger sample, and it shows that our findings are not driven only by a few firms with extraordinarily high Loan capacity. The specification in column (5) includes firm controls and industry fixed effects, while the specification in column (6) includes firm controls, year fixed effects, and firm fixed effects. In either case, we continue to find a positive and significant estimate on the interaction term, though the magnitude is slightly smaller than in the initial regressions (the coefficient is around 0.030). Together, the findings in Table 9 suggest that firms used the lending facility to increase debt levels over and above what the debt levels would have otherwise been, suggesting they faced binding credit constraints that were at least partially mitigated by the lending program. 
In Table 10 we use the matched sample approach to study the link between use of the lending facility and real outcomes. In the first four columns we estimate specification (1) with CAPX as the outcome variable, while in the last four columns the dependent variable is Employment growth. In the $C A P X$ regressions we find positive and statistically significant coefficients on the interaction term ranging from 0.002 to 0.004 depending on the sample and specification. These estimates are consistent with the findings for the full sample reported in Table 8.

Turning to Employment growth, we also find a positive and significant coefficient on the interaction term across all specifications and matched samples. The estimates suggest a positive differential effect from accessing the lending facility on employment growth of between 0.058 and 0.136, depending on the sample and specification we employ. Thus, assuming the matched samples represent the relevant counterfactual, these estimates suggest that employment growth in loan firms was between 5\% and 13\% higher than it would have otherwise been. Differential growth of this order amounts to between 1 and 3 employees for the median sized firm in our sample. ${ }^{15}$ Overall, the results in Table 10 support the earlier evidence indicating that access to the lending facility had important real effects and was not a temporary life-line for firms on the brink of insolvency.

\subsection{Elasticity of loan proceeds to debt}

At a minimum, the results thus far are consistent with the conjecture that the lending facility relaxed binding financing constraints in some firms. The tests shown above focus on overall changes in debt for the loan firms relative to the control sample, but the financing constraint conjecture also makes predictions about changes in debt within the sample of loan firms. In particular, if firms using the lending facility do face binding constraints, then debt levels should increase roughly dollar-fordollar with the amount of funding they raise from the lending facility. In other words, if financing constraints are really binding for these firms, we expect an elasticity of total debt to loan proceeds of around one.

\footnotetext{
${ }^{15}$ Note that this finding does not suggest that loan firms are rapidly expanding the number of employees during the crisis (in an absolute sense), but rather that employment growth is higher than it would have otherwise been (using matched no-loan firms as the benchmark).
} 
To test this hypothesis, we estimate the following cross-sectional regression using only the sample of loan firms:

$$
\frac{\left(\text { Debt }_{i, t}-\text { Debt }_{i, t-1}\right)}{\text { Total assets }_{i, t}}=\beta_{0}+\beta_{1} \frac{\text { Loan proceeds }_{i, t}}{\text { Total assets }_{i, t}}+\beta_{2} X_{i, t}+\varepsilon_{i, t} .
$$

The dependent variable captures the annual change in total debt from $t-1$ to $t$, which is normalized by total assets. We are then interested in the size and sign of $\beta_{1}$, which captures the elasticity of changes in debt to total loan proceeds (where loan proceeds is also normalized by total assets). The vector of control variables includes other financing sources, as well as firm size. ${ }^{16}$ We also include industry fixed effects and dummy variables indicating the year the firm took the loan (2009 or 2010).

We report estimates of specification (2) in Table 11. In the first column we estimate specification (2) with only the loan proceeds variable (no controls or fixed effects). The estimate of $\beta_{1}$ is highly significant and close to one in magnitude (1.171). The next three columns provide estimates of $\beta_{1}$ using different sets of control variables. In each case, the estimated elasticity is around one (and is never statistically different from one). These estimates show that each dollar of loan funding through the program translated into a dollar of additional debt, as expected if the loan funds relaxed constraints rather than substituted for other firm liabilities.

In the final two columns of Table 11 we estimate specification (2) with CAPX and Employment growth as the dependent variables. These regressions isolate the sensitivity of the real outcomes to the amount of funding a firm receives from the lending facility. In the capital expenditure regression, the $\beta_{1}$ coefficient is 0.171 and is highly statistically significant. This estimate indicates that, on average, $C A P X$ increases by around 17 cents for every extra dollar in loan funds a firm receives.

The $\beta_{1}$ coefficient is also positive and significant in the Employment growth regression in column (6), though here the coefficient estimate is not as straightforward to evaluate. The following back-of-the-envelope calculation provides an indication of the magnitude. The median loan firm in our sample has 24 employees. Suppose that, for this median firm, loan proceeds increase from the $25^{\text {th }}$ percentile in loan proceeds $(0.017)$ to the $75^{\text {th }}$ percentile $(0.055)$. The coefficient estimate of 1.553

\footnotetext{
${ }^{16}$ This specification is similar to the regression Kim and Weisbach (2008) use to study how firms use the proceeds from public equity issues.
} 
suggests that this change in loan proceeds would be associated with 1.4 workers in the median firm. This result is plausible, as the total wage cost of hiring/retaining 1.4 workers based on the average wages per worker in a loan firm is SEK 584,532 (78,885 US dollars), and the difference in loan proceeds between a firm at the $75^{\text {th }}$ and $25^{\text {th }}$ percentile is SEK 813,133 (109,736 US dollars). Based on these calculations, about $72 \%$ of the loan proceeds would be spent on employment (584,532/813,133). Although this is just a broad approximation and the two results are not directly comparable, these estimates line up with the finding in column (5) that $17 \%$ of each dollar of loan proceeds is spent on capital expenditures.

\section{Conclusions}

We study a novel government policy, launched in Sweden in early 2009, to evaluate how the supply of credit affects financing activity and real behavior at the firm level. The Swedish program allowed firms to postpone paying all labor-related taxes and fees, treating any unpaid taxes as a loan from the Swedish government. Using a difference-in-differences approach, we find that firms using the lending program had higher levels of debt growth, fixed investment spending, and employment growth compared to otherwise similar firms that could not benefit from the program given its structure. Moreover, firms using the lending program increased debt levels dollar-for-dollar with the amount of funding the program provided. Together, these findings indicate that the supply of credit has important effects on both financial policy (debt ratios) and real activity in at least some small, private firms.

Our study contributes to an important literature on the consequences of external financing constraints. Most notably, despite renewed interest in the external financing activities of entrepreneurial firms (e.g., Robb and Robinson, 2014), the literature offers little conclusive evidence that credit supply conditions affect the behavior of small, private firms. In particular, this literature is hampered by a lack of data on private firms and has struggled to disentangle the effects of credit supply from investment demand, particularly in times of financial and economic crisis. By combining an exogenous (policy) shock to the supply of credit with administrative data on the full economy of entrepreneurial firms, our study not only provides unique evidence that access to credit matters, but it 
also highlights the types of entrepreneurial firms that appear most affected by external credit constraints. Indeed, our work suggests that credit constraints are most relevant for a small but important slice of the economy: the growing entrepreneurial firms that have limited internal resources (cash flow and cash reserves) and relatively high debt levels. Since these types of firms comprise a relatively small share of private firms in most economies, one implication of our work is that while temporary lending programs in times of crisis can have important economic effects, broad efforts to subsidize and address perceived financing difficulties in all "small" firms may be misguided. One important task for future research is to more directly evaluate this inference, particularly in other institutional settings. 


\section{References}

Almeida, Heitor, and Murillo Campello, 2007, Financial constraints, asset tangibility, and corporate investment, Review of Financial Studies 20, 1429-1460.

Almeida Heitor, Murillo Campello, and Michael S. Weisbach, 2004, The cash flow sensitivity of cash, Journal of Finance 59, 1777-1804.

Bach, Laurent, 2014. Are small businesses worthy of financial aid? Evidence from a French targeted credit program, Review of Finance 18, 877-919.

Banerjee, Abhijit V., and Esther Duflo, 2014, Do firms want to borrow more? Testing credit constraints using a directed lending program, Review of Economic Studies 81, 572-607.

Bernanke, Ben and Mark Gertler, 1989, Agency costs, net worth, and business fluctuations, American Economic Review 79, 14-31.

Blackwell, Matthew, Stefano Iacus, Gary King, and Giuseppe Porro, 2009, CEM: Coarsened exact matching in Stata, Stata Journal 9, 524-546.

Bliss, Barbara A., Yingmei Cheng and David J. Denis, 2013, Corporate payout, cash retention, and the supply of credit: Evidence from the 2008-09 credit crisis, working paper.

Brown, James R., and Bruce C. Petersen, 2014, Which investments do firms protect? Liquidity management and real adjustments when access to finance falls sharply, Journal of Financial Intermediation, forthcoming.

Brown, James R., Steven M. Fazzari and Bruce C. Petersen, 2009, Financing innovation and growth: Cash flow, external equity and the 1990s R\&D boom, Journal of Finance 64, 151-185.

Carpenter, Robert E., Steven M. Fazzari, and Bruce C. Petersen, 1998, Financing constraints and inventory investment: A comparative study with high-frequency panel data, Review of Economics and Statistics 80, 513-519.

Campello, Murillo, John Graham, and Campbell R. Harvey, 2010, The real effects of financial constraints: evidence from a financial crisis, Journal of Financial Economics 97, 470-487.

Campello, Murillo, Erasmo Giambona, John R. Graham and Campbell R. Harvey, 2011, Liquidity management and corporate investment during a financial crisis, Review of Financial Studies 24, 1944-1979.

Cerqueiro, Geraldo, Steven Ongena, and Kasper Roszbach, 2014, Collateralization, bank loan rates, and monitoring, Journal of Finance, forthcoming.

Chen, Huafeng, and Shaojun Chen, 2012, Investment-cash flow sensitivity cannot be a good measure of financial constraints: Evidence from the time series, Journal of Financial Economics 103, 393-410.

Chodrow-Reich, Gabriel, 2014, The employment effects of credit market disruptions: Firm-level evidence from the 2008-9 financial crisis, Quarterly Journal of Economics 129, 1-59.

Duchin, Ran, Oguzhan Ozbas and Berk A. Sensoy, 2010, Costly external finance, corporate investment, and the subprime mortgage credit crisis, Journal of Financial Economics 97, 418435.

Erickson, Timothy, and Toni M. Whited, 2000, Measurement error and the relationship between investment and q, Journal of Political Economy 108, 1027-1057.

Farre-Mensa, Joan, and Alexander Ljungqvist, 2013, Do measures of financial constraints measure financial constraints? NBER Working Paper 19551. 
Fazzari, Steven M., R. Glenn Hubbard, and Bruce C. Petersen, 1988, Financing constraints and corporate investment, Brookings Paper on Economic Activity 1, 141-206.

Fazzari, Steven M., and Bruce C. Petersen, 1993, Working capital and fixed investment: New evidence on financing constraints, RAND Journal of Economics 24, 328-342.

Fee, Hadlock, Charles J., and Joshua R. Pierce, 2009, Investment, financing constraints, and internal capital markets: Evidence from the advertising expenditures of multinational firms, Review of Financial Studies 22, 2361-2392.

Hadlock, Charles J., and Joshua R. Pierce, 2010, New evidence on measuring financial constraints: Moving beyond the KZ index, Review of Financial Studies 23, 1909-1940.

Gilchrist, Simon, and Charles P. Himmelberg, 1995, Evidence on the role of cash flow for investment, Journal of Monetary Economics 36, 541-572.

Himmelberg, Charles P., and Bruce C. Petersen, 1994, R\&D and internal finance: A panel study of small firms in high-tech industries, Review of Economics and Statistics 76, 38-51.

Hurst, Erik, and Benjamin Wild Pugsley, 2011, What do small businesses do?, Brookings Papers on Economic Activity, Fall 2011, 73-118.

Iyer, Rajkamal, Samuel Lopes, Jose-Luis Peydro, and Antoinette Schoar, 2014, The interbank liquidity crunch and the firm credit crunch: Evidence from the 2007-09 crisis, Review of Financial Studies 27, 347-372.

Kahle, Kathleen M., and Rene M. Stulz, 2013, Access to capital, investment, and the financial crisis, Journal of Financial Economics 110, 280-299.

Kerr, William, and Ramana Nanda, 2009, Financing constraints and entrepreneurship, NBER working paper 15498.

Kim, Woojin, and Michael, S. Weisbach, 2008, Motivations for public equity offerings: An international perspective, Journal of Financial Economics 87, 281-307.

Lelarge, Claire, David Sraer, and David Thesmar, 2010, Entrepreneurship and credit constraints: Evidence from a French loan guarantee program. In international differences in entrepreneurship (pp. 243-273). University of Chicago Press.

Lemmon, Michael, and Michael R. Roberts, 2010, The response of corporate financing and investment changes in the supply of credit, Journal of Financial and Quantitative Analysis 45, $555-587$.

Lerner, Josh, 1999, The government as venture capitalist: The long-run impact of the SBIR program, Journal of Business 72, 285-318.

Nickell, Stephen, 1981, Biases in dynamic models with fixed effects, Econometrica, 1417-1426.

Öztekin, Özde, and Mark J. Flannery, 2012, Institutional determinants of capital structure adjustment speeds, Journal of Financial Economics 103, 88-112.

Pagano, Marco, and Giovanni Pica, 2012, Finance and employment, Economic Policy 27, 5-55.

Rauh, Joshua D., 2006, Investment and financing constraints: Evidence from the funding of corporate pension plans, Journal of Finance 61, 33-71.

Robb, Alicia M., and David T. Robinson, 2014, The capital structure decisions of new firms, Review of Financial Studies 27, 153-179. 


\section{Table 1. Summary statistics of loan program}

Table 1 reports summary statistics on the government loan program. Column (1) contains the number of firms taking the loan in each year. Column (2) contains the aggregate loan capacity of the firms in each year computed as nine percent of the total wage bill of each firm expressed in millions of Swedish Krona (MSEK). Column (3) contains the total amount of loan proceeds taken by the firms in each year. Columns (4)-(7) present the mean, $25^{\text {th }}, 50^{\text {th }}$ and $75^{\text {th }}$ percentiles in loan proceeds. The final two columns present the mean and median firm in terms of loan proceeds normalized by the book value of total assets.

\begin{tabular}{|c|c|c|c|c|c|c|c|c|c|}
\hline & \multirow[b]{2}{*}{$\begin{array}{l}\text { Nr of } \\
\text { firms }\end{array}$} & \multirow[b]{2}{*}{$\begin{array}{c}\text { Loan } \\
\text { capacity } \\
\text { (MSEK) }\end{array}$} & \multicolumn{5}{|c|}{ Amount of loan proceeds } & \multicolumn{2}{|c|}{$\begin{array}{c}\text { Loan proceeds over } \\
\text { total assets }\end{array}$} \\
\hline & & & $\begin{array}{l}\text { Total } \\
\text { (MSEK) }\end{array}$ & $\begin{array}{l}\text { Mean } \\
\left({ }^{\prime} 000\right)\end{array}$ & $\begin{array}{l}25^{\text {th }} \\
(\cdot 000)\end{array}$ & $\begin{array}{c}\text { Median } \\
\left({ }^{\prime} 000\right)\end{array}$ & $\begin{array}{l}75^{\text {th }} \\
(\cdot 000)\end{array}$ & Mean & Median \\
\hline & (1) & (2) & (3) & (4) & (5) & (6) & (7) & (8) & (9) \\
\hline 2009 & 1,109 & 5,700 & 4,280 & 3,863 & 262 & 510 & 1,076 & 0.044 & 0.031 \\
\hline 2010 & 445 & 3,270 & 364 & 818 & 142 & 321 & 590 & 0.034 & 0.020 \\
\hline
\end{tabular}




\section{Table 2. Firm and loan firm distribution across sectors in the economy}

Table 2 reports the distribution of loan firms and all firms across sectors in the economy in 2009. The sector classification is taken from Cerqueiro, Ongena, and Roszbach (2014). The sample includes all limited liability corporations in Sweden with at least five workers and one million Euros in sales and that do not operate in financial or regulated industries. Columns (1) and (2) present the total count and fraction of firms taking the loan in 2009 across sectors, and columns (3) and (4) present the total count and fraction of all firms in 2009 across sectors. Column (5) reports the average interest cost per unit of debt across all firms in the sector.

\begin{tabular}{lccccc}
\hline & Loan firms & $\begin{array}{c}\text { Sample share } \\
\text { of loan firms }\end{array}$ & All firms & $\begin{array}{c}\text { Economy } \\
\text { share of all } \\
\text { firms }\end{array}$ & $\begin{array}{c}\text { Interest cost } \\
\text { per unit of } \\
\text { debt }\end{array}$ \\
\cline { 2 - 6 } & $\mathbf{( 1 )}$ & $\mathbf{( 2 )}$ & $\mathbf{( 3 )}$ & $\mathbf{( 4 )}$ & $\mathbf{( 5 )}$ \\
\hline Agriculture & 8 & 0.007 & 420 & 0.017 & 0.039 \\
Construction & 118 & 0.106 & 3,621 & 0.144 & 0.026 \\
Hotels and restaurants & 46 & 0.041 & 788 & 0.031 & 0.032 \\
Manufacturing & 361 & 0.326 & 4,701 & 0.186 & 0.040 \\
Other services & 250 & 0.225 & 4,449 & 0.176 & 0.027 \\
Real estate & 6 & 0.005 & 399 & 0.016 & 0.039 \\
Retail and trade & 207 & 0.187 & 8,127 & 0.322 & 0.041 \\
Transport & 76 & 0.069 & 1,732 & 0.069 & 0.035 \\
Other industries & 37 & 0.033 & 972 & 0.039 & 0.043 \\
Total & 1,109 & 1.000 & 25,209 & 1.000 & 0.035 \\
\hline
\end{tabular}




\section{Table 3. Firm characteristics}

Table 3 reports summary statistics of the variables used in this study. The sample period is 2007-2010 and the sample includes all limited liability corporations in Sweden with at least five workers and one million Euros in sales and that do not operate in financial or regulated industries. The first column reports mean, median and standard deviation for loan firms, and the second column reports the same values for firms not taking the loan. Debt growth is the annual change in total debt divided by the book value of total assets, CAPX is capital expenditures divided by the book value of total assets, Employment growth is the annual change in log total employment, Cash flow is cash flow divided by the book value of total assets, Debt is total debt divided by the book value of total assets, Firm age is years since incorporation, Cash is cash holdings divided by the book value of total assets, Dividend is dividends divided by the book value of total assets, Sales growth is the annual change in log net sales, Sales is net sales divided by the book value of total assets, Wage bill is the natural logarithm of the total wage bill, Loan capacity is computed as $0.09 *$ wage bill divided by the book value of total assets, and Loan amount is loan proceeds divided by the book value of total assets.

\begin{tabular}{|c|c|c|}
\hline & \multicolumn{2}{|c|}{ All firms 2007-2010 } \\
\hline & Loan firms & Other firms \\
\hline \multicolumn{3}{|l|}{ Debt growth } \\
\hline Mean & 0.016 & -0.005 \\
\hline Median & 0.014 & -0.006 \\
\hline Standard deviation & 0.154 & 0.129 \\
\hline \multicolumn{3}{|l|}{ CAPX } \\
\hline Mean & 0.051 & 0.044 \\
\hline Median & 0.034 & 0.026 \\
\hline Standard deviation & 0.054 & 0.049 \\
\hline \multicolumn{3}{|l|}{ Employment growth } \\
\hline Mean & 0.040 & 0.040 \\
\hline Median & 0.012 & 0.000 \\
\hline Standard deviation & 0.497 & 0.387 \\
\hline \multicolumn{3}{|l|}{ Cash flow } \\
\hline Mean & 0.063 & 0.131 \\
\hline Median & 0.050 & 0.105 \\
\hline Standard deviation & 0.190 & 0.166 \\
\hline \multicolumn{3}{|l|}{ Debt } \\
\hline Mean & 0.585 & 0.418 \\
\hline Median & 0.603 & 0.403 \\
\hline Standard deviation & 0.211 & 0.219 \\
\hline \multicolumn{3}{|l|}{ Firm age } \\
\hline Mean & 2.857 & 2.882 \\
\hline Median & 2.944 & 2.944 \\
\hline Standard deviation & 0.814 & 0.774 \\
\hline
\end{tabular}


Cash

\begin{tabular}{|c|c|c|}
\hline Mean & 0.072 & 0.194 \\
\hline Median & 0.016 & 0.120 \\
\hline Standard deviation & 0.171 & 0.236 \\
\hline \multicolumn{3}{|l|}{ Dividend } \\
\hline Mean & 0.016 & 0.046 \\
\hline Median & 0.000 & 0.008 \\
\hline Standard deviation & 0.051 & 0.083 \\
\hline \multicolumn{3}{|l|}{ Sales growth } \\
\hline Mean & 0.025 & 0.016 \\
\hline Median & 0.005 & 0.018 \\
\hline Standard deviation & 0.475 & 0.403 \\
\hline \multicolumn{3}{|l|}{ Sales } \\
\hline Mean & 2.360 & 2.629 \\
\hline Median & 1.913 & 2.040 \\
\hline Standard deviation & 1.917 & 2.192 \\
\hline \multicolumn{3}{|l|}{ Wage bill } \\
\hline Mean & 16.074 & 15.751 \\
\hline Median & 16.006 & 15.648 \\
\hline Standard deviation & 1.009 & 1.004 \\
\hline \multicolumn{3}{|l|}{ Loan capacity } \\
\hline Mean & 0.075 & 0.064 \\
\hline Median & 0.053 & 0.046 \\
\hline Standard deviation & 0.069 & 0.060 \\
\hline \multicolumn{3}{|l|}{ Loan amount } \\
\hline Mean & 0.041 & 0.000 \\
\hline Median & 0.027 & 0.000 \\
\hline Standard deviation & 0.058 & 0.000 \\
\hline
\end{tabular}




\section{Table 4. Logit regression results}

Table 4 reports logit estimates on the link between firm characteristics and the likelihood a firm uses the lending facility. The dependent variable takes on the value of one if the firm takes the loan in 2009 and zero otherwise. Firm characteristics are measured in 2008. The regression sample includes all limited liability corporations in Sweden with at least five workers and one million Euros in sales and that do not operate in financial or regulated industries. Cash flow is cash flow divided by the book value of total assets, Firm age is years since incorporation, Cash is cash holdings divided by the book value of total assets, Dividend is dividends divided by the book value of total assets, Sales growth is the annual change in log net sales, Sales is net sales divided by the book value of total assets, Wage bill is the natural logarithm of the total wage bill, Debt is total debt divided by the book value of total assets, $C A P X$ is capital expenditures divided by the book value of total assets, Employment growth is the annual change in log total employment, and Loan capacity is computed as $0.09^{*}$ wage bill divided by the book value of total assets. Standard errors (in parenthesis) are clustered at the firm level. ***, ${ }^{* *}$, and ${ }^{*}$ stand for significance levels at $1 \%, 5 \%$, and $10 \%$ respectively.

\begin{tabular}{lcc}
\hline & $\mathbf{( 1 )}$ & $\mathbf{( 2 )}$ \\
\cline { 2 - 3 } Cash flow & -1.884 & -1.873 \\
Firm age & $(0.342)^{* * *}$ & $(0.335)^{* * *}$ \\
Cash & -0.128 & -0.092 \\
& $(0.042)^{* * *}$ & $(0.042)^{* *}$ \\
Dividend & -3.570 & -3.851 \\
& $(0.477)^{* * *}$ & $(0.500)^{* * *}$ \\
Sales growth & -4.052 & -4.249 \\
& $(1.142)^{* * *}$ & $(1.144)^{* * *}$ \\
Sales & 0.550 & 0.578 \\
& $(0.089)^{* * *}$ & $(0.091)^{* * *}$ \\
Wage bill & 0.063 & 0.042 \\
& $(0.016)^{* * *}$ & $(0.025)^{*}$ \\
Debt & 0.312 & 0.235 \\
CAPX & $(0.071)^{* * *}$ & $(0.073)^{* * *}$ \\
& 2.540 & 2.304 \\
Employment growth & $(0.166)^{* * *}$ & $(0.170)^{* * *}$ \\
Loan capacity & 1.494 & 1.262 \\
& $(0.732)^{* *}$ & $(0.748)^{*}$ \\
Industry fixed effects & 0.115 & 0.137 \\
Observations & $(0.061)^{*}$ & $(0.061)^{* *}$ \\
Pseudo R-squared & - & 4.677 \\
& & $(0.693)^{* * *}$ \\
\hline
\end{tabular}




\section{Table 5. Fraction of loan firms and loan amounts across Loan capacity quartiles}

Table 5 reports statistics on loan firms (Panel A) and loan proceeds (Panel B) across different Loan capacity quartiles. Loan capacity is computed as $0.09 *$ wage bill divided by the book value of total assets, and Loan amount is loan proceeds divided by the book value of total assets. Column (1) reports statistics for all loan firms in 2009. Columns (2)-(5) divides the loan firms into quartiles in terms of Loan capacity, with Q1 representing firms in the bottom quartile in Loan capacity and Q4 subsequently firms in the top quartile in Loan capacity.

\begin{tabular}{lccccc}
\hline Loan capacity quartile: & All & Q1 & Q2 & Q3 & Q4 \\
\cline { 2 - 6 } & $\mathbf{( 1 )}$ & $\mathbf{( 2 )}$ & $\mathbf{( 3 )}$ & $\mathbf{( 4 )}$ & (5) \\
\cline { 2 - 6 } & \multicolumn{5}{c}{ Panel A: Loan firms } \\
Fraction of firms & 0.044 & 0.036 & 0.042 & 0.046 & 0.052 \\
Total nr of firms & 1,109 & 226 & 263 & 288 & 332 \\
& \multicolumn{5}{c}{ Panel B: Loan amount } \\
\cline { 2 - 6 } Mean & 0.044 & 0.011 & 0.023 & 0.038 & 0.088 \\
25th & 0.017 & 0.005 & 0.016 & 0.026 & 0.053 \\
Median & 0.031 & 0.009 & 0.022 & 0.037 & 0.073 \\
75th & 0.055 & 0.016 & 0.028 & 0.048 & 0.105 \\
\hline
\end{tabular}




\section{Table 6. Summary statistics for the matched sample}

Table 6 reports summary statistics across treated and control firms. Columns (1) and (2) reports firm averages for 2007-2008 for the treated firms and control group firms. Column (3) reports the difference between column (1) and (2) and column (4) reports the p-value of the difference in means. The treated firms are firms taking the loan and that are in the top quartile in Loan capacity. The control group is drawn from firms in the bottom quartile in Loan capacity during 2007-2008. These firms are then matched using coarsened exact matching within each industry and for Debt, CAPX, Employment, Cash flow, Cash, and Dividend. The matching is based on values for 2008. Debt is total debt divided by the book value of total assets, $C A P X$ is capital expenditures divided by the book value of total assets, Employment is the natural logarithm of total employment, Cash flow is cash flow divided by the book value of total assets, Cash is cash holdings divided by the book value of total assets, and Dividend is dividends divided by the book value of total assets. ***, **, and * stand for significance levels at $1 \%, 5 \%$, and $10 \%$ respectively.

\begin{tabular}{lcccc}
\hline & Treated firms & Control firms & Difference & p-value \\
\cline { 2 - 5 } & $\mathbf{( 1 )}$ & $\mathbf{( 2 )}$ & $\mathbf{( 3 )}$ & $\mathbf{( 4 )}$ \\
\cline { 2 - 5 } Debt & 0.557 & 0.557 & 0.001 & 0.965 \\
CAPX & 0.029 & 0.020 & 0.009 & $0.000^{* * *}$ \\
Employment & 3.048 & 2.615 & 0.434 & $0.000^{* * *}$ \\
Cash flow & 0.052 & 0.043 & 0.009 & $0.049^{* *}$ \\
Cash & 0.037 & 0.031 & 0.006 & $0.095^{*}$ \\
Dividend & 0.006 & 0.007 & -0.001 & 0.546 \\
\cline { 2 - 5 } Nr of firms & & & & - \\
\hline
\end{tabular}




\section{Table 7. Regression analysis: Debt growth}

Table 7 reports results with ordinary least squares (OLS) estimation with Debt growth as the dependent variable. The sample period is 2007-2010 and the sample includes all limited liability corporations in Sweden with at least five workers and one million Euros in sales and that do not operate in financial or regulated industries. $L P$ is an indicator variable taking on the value one in the years when the lending facility is available (2009 and 2010) and zero otherwise. $L F$ is an indicator variable taking on the value one if it is a loan firm and zero otherwise. Debt growth is the annual change in total debt divided by the book value of total assets, Debt is total debt divided by the book value of total assets, Cash flow is cash flow divided by the book value of total assets, Firm age is years since incorporation, Cash is cash holdings divided by the book value of total assets, Dividend is dividends divided by the book value of total assets, Sales growth is the annual change in log net sales, Sales is net sales divided by the book value of total assets, and Wage bill is the natural logarithm of the total wage bill. Standard errors clustered at the firm level are in parenthesis. ***, **, and * stand for significance levels at $1 \%$, $5 \%$, and $10 \%$ respectively.

\begin{tabular}{|c|c|c|c|c|c|c|}
\hline & (1) & (2) & (3) & (4) & (5) & (6) \\
\hline \multirow[t]{2}{*}{ Loan firm $\times$ Loan period } & 0.023 & 0.023 & 0.024 & 0.025 & 0.015 & 0.017 \\
\hline & $(0.005)^{* * *}$ & $(0.005)^{* * *}$ & $(0.004)^{* * *}$ & $(0.004)^{* * *}$ & $(0.005)^{* * *}$ & $(0.005)^{* * *}$ \\
\hline \multirow[t]{2}{*}{ Loan firm $\left(L F_{i}\right)$} & 0.014 & 0.014 & 0.026 & 0.026 & - & - \\
\hline & $(0.002)^{* * *}$ & $(0.002)^{* * *}$ & $(0.002)^{* * *}$ & $(0.002)^{* * *}$ & & \\
\hline \multirow[t]{2}{*}{ Loan period $\left(L P_{t}\right)$} & -0.015 & -0.014 & -0.008 & - & -0.014 & - \\
\hline & $(0.001)^{* * *}$ & $(0.001)^{* * *}$ & $(0.001)^{* * *}$ & & $(0.001)^{* * *}$ & \\
\hline \multirow{2}{*}{$\operatorname{Debt}_{t-1}$} & - & - & -0.195 & -0.195 & - & - \\
\hline & & & $(0.003)^{* * *}$ & $(0.003) * * *$ & & \\
\hline \multirow[t]{2}{*}{ Cash flow } & - & - & -0.148 & -0.147 & -0.235 & -0.233 \\
\hline & & & $(0.005)^{* * *}$ & $(0.005) * * *$ & $(0.008) * * *$ & $(0.008)^{* * *}$ \\
\hline \multirow[t]{2}{*}{ Firm age } & - & - & -0.006 & -0.007 & 0.013 & 0.002 \\
\hline & & & $(0.001)^{* * *}$ & $(0.001)^{* * *}$ & $(0.004)^{* * *}$ & $(0.004)$ \\
\hline \multirow[t]{2}{*}{ Cash } & - & - & -0.041 & -0.042 & 0.046 & 0.044 \\
\hline & & & $(0.003)^{* * *}$ & $(0.003) * * *$ & $(0.007)^{* * *}$ & $(0.007)^{* * *}$ \\
\hline \multirow[t]{2}{*}{ Dividend } & - & - & 0.012 & 0.013 & 0.055 & 0.056 \\
\hline & & & $(0.006)^{* *}$ & $(0.006)^{* *}$ & $(0.012)^{* * *}$ & $(0.011)^{* * *}$ \\
\hline \multirow[t]{2}{*}{ Sales growth } & - & - & 0.017 & 0.032 & -0.003 & -0.002 \\
\hline & & & $(0.002)^{* * *}$ & $(0.002) * * *$ & $(0.003)$ & $(0.003)$ \\
\hline \multirow[t]{2}{*}{ Sales } & - & - & 0.005 & 0.005 & 0.015 & 0.015 \\
\hline & & & $(0.000)^{* * *}$ & $(0.000)^{* * *}$ & $(0.001)^{* * *}$ & $(0.001)^{* * *}$ \\
\hline \multirow[t]{2}{*}{ Wage bill } & - & - & -0.002 & -0.002 & 0.019 & 0.018 \\
\hline & & & $(0.000)^{* * *}$ & $(0.000)^{* * *}$ & $(0.002)^{* * *}$ & $(0.002)^{* * *}$ \\
\hline Industry fixed effects & No & Yes & Yes & Yes & No & No \\
\hline Firm controls & No & No & Yes & Yes & Yes & Yes \\
\hline Year fixed effects & No & No & No & Yes & No & Yes \\
\hline Firm fixed effects & No & No & No & No & Yes & Yes \\
\hline Observations & 99,061 & 99,061 & 97,381 & 97,381 & 97,381 & 97,381 \\
\hline Adjusted R-squared & 0.005 & 0.006 & 0.125 & 0.128 & 0.018 & 0.021 \\
\hline
\end{tabular}




\section{Table 8. Regression analysis: Investment and employment growth}

Table 8 reports results with ordinary least squares (OLS) estimation with CAPX (columns (1)-(3)) and Employment growth (columns (4)-(6)) as the dependent variables. The sample period is 2007-2010 and the sample includes all limited liability corporations in Sweden with at least five workers and one million Euros in sales and that do not operate in financial or regulated industries. $L P$ is an indicator variable taking on the value one in the years when the lending facility is available (2009 and 2010) and zero otherwise. $L F$ is an indicator variable taking on the value one if it is a loan firm and zero otherwise. CAPX is capital expenditures divided by the book value of total assets, Employment growth is the annual change in log total employment, Employment is the natural logarithm of total employment, Cash flow is cash flow divided by the book value of total assets, Firm age is years since incorporation, Cash is cash holdings divided by the book value of total assets, Dividend is dividends divided by the book value of total assets, Sales growth is the annual change in log net sales, Sales is net sales divided by the book value of total assets, and Wage bill is the natural logarithm of the total wage bill. Standard errors clustered at the firm level are in parenthesis. ***,**, and * stand for significance levels at $1 \%$, $5 \%$, and $10 \%$ respectively.

\begin{tabular}{|c|c|c|c|c|c|c|}
\hline & (1) & (2) & (3) & (4) & (5) & (6) \\
\hline Dependent variable & & CAPX & & \multicolumn{3}{|c|}{ Employment growth } \\
\hline \multirow[t]{2}{*}{ Loan firm $\times$ Loan period } & 0.002 & 0.002 & 0.002 & 0.046 & 0.029 & 0.032 \\
\hline & $(0.001)^{* *}$ & $(0.001)^{* *}$ & $(0.001)^{* * *}$ & $(0.012)^{* * *}$ & $(0.012)^{* *}$ & $(0.014)^{* *}$ \\
\hline \multirow{2}{*}{ Loan firm $\left(L F_{i}\right)$} & 0.003 & 0.003 & - & -0.003 & 0.002 & - \\
\hline & $(0.001)^{* * *}$ & $(0.001)^{* * *}$ & & $(0.006)$ & $(0.006)$ & \\
\hline \multirow[t]{2}{*}{ Loan period $\left(L P_{t}\right)$} & 0.004 & - & 0.000 & -0.030 & - & -0.072 \\
\hline & $(0.000)^{* * *}$ & & $(0.000)$ & $(0.002)^{* * *}$ & & $(0.003)^{* * *}$ \\
\hline \multirow[t]{2}{*}{$C A P X_{t-1}$} & 0.582 & 0.583 & - & - & - & - \\
\hline & $(0.006)^{* * *}$ & $(0.006)^{* * *}$ & & & & \\
\hline \multirow{2}{*}{ Employment $_{t-1}$} & - & - & - & -0.283 & -0.282 & - \\
\hline & & & & $(0.008)^{* * *}$ & $(0.008)^{* * *}$ & \\
\hline \multirow[t]{2}{*}{ Cash flow } & 0.062 & 0.063 & 0.034 & -0.001 & 0.004 & -0.080 \\
\hline & $(0.002)^{* * *}$ & $(0.002)^{* * *}$ & $(0.002)^{* * *}$ & $(0.015)$ & $(0.014)$ & $(0.024)^{* * *}$ \\
\hline \multirow[t]{2}{*}{ Firm age } & 0.001 & 0.001 & 0.005 & 0.011 & 0.011 & 0.001 \\
\hline & $(0.000)^{* * *}$ & $(0.000)^{* * *}$ & $(0.001)^{* * *}$ & $(0.002)^{* * *}$ & $(0.002)^{* * *}$ & $(0.014)$ \\
\hline \multirow[t]{2}{*}{ Cash } & -0.012 & -0.012 & -0.001 & -0.016 & -0.018 & 0.154 \\
\hline & $(0.001)^{* * *}$ & $(0.001)^{* * *}$ & $(0.001)$ & $(0.007)^{* *}$ & $(0.007)^{* *}$ & $(0.019)^{* * *}$ \\
\hline \multirow[t]{2}{*}{ Dividend } & -0.058 & -0.057 & -0.014 & -0.073 & -0.068 & 0.126 \\
\hline & $(0.002)^{* * *}$ & $(0.002)^{* * *}$ & $(0.002)^{* * *}$ & $(0.019)^{* * *}$ & $(0.019)^{* * *}$ & $(0.036)^{* * *}$ \\
\hline \multirow[t]{2}{*}{ Sales growth } & 0.011 & 0.011 & 0.003 & 0.312 & 0.319 & 0.303 \\
\hline & $(0.000)^{* * *}$ & $(0.001)^{* * *}$ & $(0.000)^{* * *}$ & $(0.009)^{* * *}$ & $(0.009)^{* * *}$ & $(0.013)^{* * *}$ \\
\hline \multirow[t]{2}{*}{ Sales } & 0.002 & 0.002 & 0.007 & 0.013 & 0.013 & 0.016 \\
\hline & $(0.000)^{* * *}$ & $(0.000)^{* * *}$ & $(0.000)^{* * *}$ & $(0.001)^{* * *}$ & $(0.001)^{* * *}$ & $(0.004)^{* * *}$ \\
\hline \multirow[t]{2}{*}{ Wage bill } & -0.001 & -0.001 & 0.001 & 0.301 & 0.298 & 0.403 \\
\hline & $(0.000)^{* * *}$ & $(0.000)^{* * *}$ & $(0.000)^{* * *}$ & $(0.008) * * *$ & $(0.008)^{* * *}$ & $(0.016)^{* * *}$ \\
\hline Industry fixed effects & Yes & Yes & No & Yes & Yes & No \\
\hline Firm controls & Yes & Yes & Yes & Yes & Yes & Yes \\
\hline Year fixed effects & No & Yes & No & No & Yes & No \\
\hline Firm fixed effects & No & No & Yes & No & No & Yes \\
\hline Observations & 95,297 & 95,297 & 97,381 & 96,045 & 96,045 & 96,045 \\
\hline Adjusted R-squared & 0.638 & 0.638 & 0.029 & 0.388 & 0.392 & 0.076 \\
\hline
\end{tabular}




\section{Table 9. Regression analysis with matched sample: Debt growth}

Table 9 reports results with ordinary least squares (OLS) estimation with Debt growth as the dependent variable. The sample period is 2007-2010. Columns (1)-(4) use the main matched sample where we perform coarsened exact matching of loan firms from the top quartile in loan capacity (treated) to the no loan firms in the bottom quartile (control group). See Table 6 for summary statistics from the matching approach. Columns (5)-(6) report results using an expanded group of treated firms using all loan firms in the top three quartiles in loan capacity. $L P$ is an indicator variable taking on the value one in the years when the lending facility is available (2009 and 2010) and zero otherwise. $L F$ is an indicator variable taking on the value one if it is a loan firm and zero otherwise. Columns (3)-(6) include the following firm controls: Cash flow (cash flow divided by the book value of total assets,) Firm age (years since incorporation), Cash (cash holdings divided by the book value of total assets), Dividend (dividends divided by the book value of total assets), Sales growth (annual change in log net sales), Sales (net sales divided by the book value of total assets), and Wage bill (natural logarithm of the total wage bill). Standard errors clustered at the firm level are in parenthesis. ***, **, and * stand for significance levels at $1 \%, 5 \%$, and $10 \%$ respectively.

\begin{tabular}{lcccccc}
\hline & $\mathbf{( 1 )}$ & $\mathbf{( 2 )}$ & $\mathbf{( 3 )}$ & $\mathbf{( 4 )}$ & $\mathbf{( 5 )}$ & $\mathbf{( 6 )}$ \\
\hline \multicolumn{1}{c}{ Treatment group: } & \multicolumn{2}{c}{ Top quartile } & & \multicolumn{2}{c}{ Top three quartiles } \\
\cline { 2 - 7 } Loan firm $\times$ Loan period & 0.048 & 0.049 & 0.037 & 0.042 & 0.030 & 0.033 \\
& $(0.012)^{* * *}$ & $(0.013)^{* * *}$ & $(0.012)^{* * *}$ & $(0.013)^{* * *}$ & $(0.008)^{* * *}$ & $(0.008)^{* * *}$ \\
Loan firm $\left(L F_{i}\right)$ & 0.005 & - & 0.006 & - & -0.001 & - \\
& $(0.006)$ & & $(0.006)$ & & $(0.004)$ & \\
Loan period $\left(L P_{t}\right)$ & -0.041 & - & -0.036 & - & -0.032 & - \\
& $(0.005)^{* * *}$ & & $(0.005)^{* * *}$ & & $(0.004)^{* * *}$ & \\
\cline { 2 - 7 } Industry fixed effects & No & No & Yes & No & Yes & No \\
Firm controls & No & No & Yes & Yes & Yes & Yes \\
Year fixed effects & No & Yes & No & Yes & No & Yes \\
Firm fixed effects & No & Yes & No & Yes & No & Yes \\
& & & & & & \\
Observations & 2,927 & 2,927 & 2,882 & 2,882 & 4,989 & 4,989 \\
Adjusted R-squared & 0.026 & 0.034 & 0.062 & 0.041 & 0.068 & 0.054 \\
\hline
\end{tabular}




\section{Table 10. Regression analysis with matched sample: Investment and employment growth}

Table 10 reports results with ordinary least squares (OLS) estimation with CAPX (columns (1)-(4)) and Employment growth (columns (5)-(8)) as the dependent variables. The sample period is 2007-2010. Columns (1)-(2) and (5)-(6) use the main matched sample where we perform coarsened exact matching of loan firms from the top quartile in loan capacity (treated) to the no loan firms in the bottom quartile (control group). Columns (3)-(4) and (7)-(8) report results using an expanded group of treated firms using all loan firms in the top three quartiles in loan capacity. $L P$ is an indicator variable taking on the value one in the years when the lending facility is available (2009 and 2010) and zero otherwise. $L F$ is an indicator variable taking on the value one if it is a loan firm and zero otherwise. All regressions include the following firm controls: Cash flow (cash flow divided by the book value of total assets,) Firm age (years since incorporation), Cash (cash holdings divided by the book value of total assets), Dividend (dividends divided by the book value of total assets), Sales growth (annual change in log net sales), Sales (net sales divided by the book value of total assets), and Wage bill (natural logarithm of the total wage bill). Standard errors clustered at the firm level are in parenthesis. ***, **, and * stand for significance levels at $1 \%, 5 \%$, and $10 \%$ respectively.

\begin{tabular}{|c|c|c|c|c|c|c|c|c|}
\hline & (1) & (2) & (3) & (4) & (5) & (6) & (7) & (8) \\
\hline Dependent variable & \multicolumn{4}{|c|}{ CAPX } & \multicolumn{4}{|c|}{ Employment growth } \\
\hline Treatment group: & \multicolumn{2}{|c|}{ Top quartile } & \multicolumn{2}{|c|}{ Top three quartiles } & \multicolumn{2}{|c|}{ Top quartile } & \multicolumn{2}{|c|}{ Top three quartiles } \\
\hline Loan firm $\times$ Loan period & $\begin{array}{c}0.004 \\
(0.002)^{*}\end{array}$ & $\begin{array}{c}0.004 \\
(0.002)^{*}\end{array}$ & $\begin{array}{c}0.003 \\
(0.001)^{* *}\end{array}$ & $\begin{array}{c}0.002 \\
(0.001)^{*}\end{array}$ & $\begin{array}{c}0.136 \\
(0.049)^{* * *}\end{array}$ & $\begin{array}{c}0.111 \\
(0.047)^{* *}\end{array}$ & $\begin{array}{c}0.098 \\
(0.026)^{* * *}\end{array}$ & $\begin{array}{c}0.058 \\
(0.025)^{* *}\end{array}$ \\
\hline Loan firm $\left(L F_{i}\right)$ & $\begin{array}{c}0.002 \\
(0.002)\end{array}$ & - & $\begin{array}{c}0.003 \\
(0.001)^{* *}\end{array}$ & - & $\begin{array}{c}-0.056 \\
(0.031)^{*}\end{array}$ & - & $\begin{array}{c}-0.039 \\
(0.016)^{* *}\end{array}$ & - \\
\hline Loan period $\left(L P_{t}\right)$ & $\begin{array}{c}0.003 \\
(0.001)^{* * *}\end{array}$ & - & $\begin{array}{c}0.003 \\
(0.001)^{* * *}\end{array}$ & - & $\begin{array}{c}-0.062 \\
(0.014)^{* * *}\end{array}$ & - & $\begin{array}{c}-0.074 \\
(0.011)^{* * *}\end{array}$ & - \\
\hline Industry fixed effects & Yes & No & Yes & No & Yes & No & Yes & No \\
\hline Firm controls & Yes & Yes & Yes & Yes & Yes & Yes & Yes & Yes \\
\hline Year fixed effects & No & Yes & No & Yes & No & Yes & No & Yes \\
\hline Firm fixed effects & No & Yes & No & Yes & No & Yes & No & Yes \\
\hline Observations & 2,882 & 2,882 & 4,989 & 4,989 & 2,856 & 2,856 & 4,939 & 4,939 \\
\hline Adjusted R-squared & 0.373 & 0.053 & 0.356 & 0.025 & 0.229 & 0.051 & 0.240 & 0.064 \\
\hline
\end{tabular}




\section{Table 11. Regression analysis with loan firm sample: Loan proceed elasticities}

Table 11 reports results with ordinary least squares (OLS) estimation with (Debt ${ }_{t}$ - Debt ${ }_{t-1}$ )/total assets (columns (1)-(4)), CAPX (column (5)) and Employment growth (columns (6)) as dependent variables. The sample contains all firm-year observations taking a loan. CAPX is capital expenditures divided by the book value of total assets, Employment growth is the annual change in log total employment, Loan amount is loan proceeds divided by the book value of total assets, Cash flow is cash flow divided by the book value of total assets, Cash is cash holdings divided by the book value of total assets, Dividend is dividends divided by the book value of total assets, and Wage bill is the natural logarithm of the total wage bill. Standard errors clustered at the firm level are in parenthesis. $* * *, * *$, and ${ }^{*}$ stand for significance levels at $1 \%, 5 \%$, and $10 \%$ respectively.

\begin{tabular}{|c|c|c|c|c|c|c|}
\hline & (1) & (2) & (3) & (4) & (5) & (6) \\
\hline Dependent variable & & $\left(\operatorname{Debt}_{t}-\right.$ Debt $_{t}$ & )/total assets & & CAPX & $\begin{array}{l}\text { Employment } \\
\text { growth }\end{array}$ \\
\hline \multirow[t]{2}{*}{ Loan amount } & 1.171 & 1.264 & 1.002 & 0.901 & 0.171 & 1.553 \\
\hline & $(0.333)^{* * *}$ & $(0.407)^{* * *}$ & $(0.377)^{* * *}$ & $(0.255)^{* * *}$ & $(0.029) * * *$ & $(0.578) * * *$ \\
\hline \multirow[t]{2}{*}{ Cash flow } & - & - & -0.136 & -0.021 & 0.081 & 0.311 \\
\hline & & & $(0.143)$ & $(0.054)$ & $(0.013)^{* * *}$ & $(0.127)^{* *}$ \\
\hline \multirow[t]{2}{*}{ Cash } & - & - & 0.379 & 0.148 & -0.036 & 0.162 \\
\hline & & & $(0.218)^{*}$ & $(0.097)$ & $(0.018)^{* *}$ & $(0.266)$ \\
\hline \multirow[t]{2}{*}{ Dividend } & - & - & 0.207 & -0.108 & -0.027 & 1.171 \\
\hline & & & $(0.267)$ & $(0.208)$ & $(0.035)$ & $(0.549) * *$ \\
\hline \multirow[t]{2}{*}{ Wage bill } & - & - & - & 0.057 & -0.001 & 0.089 \\
\hline & & & & $(0.014)^{* * * *}$ & $(0.001)$ & $(0.019) * * *$ \\
\hline Industry fixed effects & No & Yes & Yes & Yes & Yes & Yes \\
\hline Year fixed effects & No & Yes & Yes & Yes & Yes & Yes \\
\hline Observations & 1,544 & 1,544 & 1,544 & 1,544 & 1,539 & 1,512 \\
\hline Adjusted R-squared & 0.003 & 0.027 & 0.027 & 0.047 & 0.277 & 0.142 \\
\hline
\end{tabular}

